\title{
Is Weight a Reliable Index to Age in Microtine Rodents?
}

\author{
William A. FULLER
}

Fuller W. A., 1988: Is weight a reliable index to age in microtine rodents? Acta theriol., 33, $17: 247-261$ [With 9 Tables \& 4 Figs.]

Frequency distributions of "age" classes based on body weights and on molar development and morphology are compared both within and among years in samples of Clethrionomys gapperi. Weight class limits that give the best fit to molar class frequencies vary from year to year. Body weight is a poor predictor of the molar class of an individual. Weight class limits determined from all age classes in a sample gave poor results when applied to the sexually mature component only. In interyear comparisons, body weight and molar morphology gave conflicting views of differences in age structure, and hence of the dynamics of the population. Body weight should be used with caution as an index to age of Clethrionomys, and by extension, to other microtine rodents.

[Department of Zoology, University of Alberta, Edmonton, Alberta T6G 2E9, Canada]

\section{INTRODUCTION}

Body weight is used frequently as an index to the age of individuals in populations of microtine rodents, especially Microtus spp. Demographic conclusions are then drawn from frequency distributions, and other analyses, of the putative "ages". Inherent in any index based on the equivalence of weight and age is the assumption that growth rates are constant between years and seasons, and that they are independent of the season of birth of the individuals in the population. None of those assumptions is known to be true. Growth rates do vary from season to season and from year to year in Clethrionomys gapperi (Vigors, 1830) (Fuller 1977) and C. glareolus (Schreber, 1780) (Zejda 1971). It has long been known that in temperate and boreal regions, at least, individuals born early in the breeding season complete their growth quickly, whereas those born late in the season only complete their growth in the following summer (Schwarz et al. 1964 and others).

An ideal test of the validity of body weight as an index to age would require a large sample of known-aged individuals born in different years and different seasons, and raised under "natural" conditions. A less reliable approach is to use a morphological indicator of age in place of known-aged individuals. Such an indicator is available for the genera Clethrionomys, Phenacomys, and Ondatra in North America, and Dolomys in Europe, all of which develop roots on their molar teeth. 
A number of investigators have used the developmental sequence of changes in a molar tooth as an index to age in Clethrionomys spp. Koshkina (1955) studied a series of skulls of both C. rufocanus Sundevall, 1846 and C. glareolus. She showed that development of the molars proceeded more slowly in C. rufocanus than in C. glareolus, but she noted that in the latter species, roots appeared at 2-2.5 months of age, which made it possible to recognize survivors of the first litter of the spring in late summer samples. Koshkina attempted to estimate the age of overwintered animals by means of the ratio between root length and stotal length of the tooth. Tupikova et al. (1968) also used ratios to estimate age, to the nearest month, of older individuals of both C. glareolus and C. rutilus Pallas, 1779. Martell and Fuller (1979) used the second upper molar $\left(\mathrm{M}^{2}\right)$ to define 4 molar "age" classes in C. rutilus in arctic Canada.

Zejda (1965) estimated age in months of individuals of C. glareolus according to the length of root on the first lower molar $\left(\mathrm{M}_{1}\right)$. He found a correlation between weight and age in sexually inactive individuals up to an age of 4 months. Among the sexually active component of his sample, a correlation was also found, but the breadth of variation was considerable in both sexes. He could not distinguish between overwintered individuals and young of the current year by weight alone during the breeding season, and he noted that after the gonads regressed there was a progressive diminution of body weight.

Wasilewski (1952, cited by Koshkina, 1955) raised C. glareolus in, captivity and determined that roots appeared at about 2 months of age. In a sample of known-aged individuals of C. gapperi, morphological changes in $\mathrm{M}^{2}$ took place predictably, and with little chronological variation (Mihok, 1980). Beginning of neck formation (closure of the anterior labial groove), occurred between 32 and 35 days of age, and measurable roots $(\geqslant 0.1 \mathrm{~mm})$ appeared between 62 and 72 days of age, the variability being at least partly due to the presence of both sexually mature and immature individuals in the sample. Thus, molar development in Clethrionomys appears to be under rather precise genetic control, and four "molar age classes" can be recognized in C. gapperi as in C. rutilus (Martell \& Fuller 1979). Class 1 individuals have the anterior labial groove of $\mathrm{M}^{2}$ open to the proximal end of the tooth. Class 2 a individuals have the groove closed (i.e. neck is forming), but no measurable root. In Class 3 , short roots, usually $<0.5 \mathrm{~mm}$ in length, are present. Individuals that have survived a winter (Class 4 , or OW), have long roots, usually $>0.8 \mathrm{~mm}$ in May, and up to $2.0 \mathrm{~mm}$ by the end of summer. In this paper I address four questions:

(1) Is there a frequency distribution of body weight classes that 
matches that of classes based on molar morphology? If so, what are the appropriate class limits for each class and for each sex, and are they constant from year to year?

(2) Do the criteria developed in (1) apply to subsamples of sexually mature individuals?

(3) Do both indices select the same individuals, i.e. can the molar class of an individual be determined correctly from the body weight of that individual?

(4) In interyear comparisons, does "age" structure vary in the same way from year to year when (a) molar morphology and (b) body weight is used as an index to age?

\section{MATERIALS}

Material consists of body weight and molar age class of 415 male and 368 females C. gapperi captured in snap traps in the years 1974, 1976, and 1978. Those years provide a contrast in environmental and demographic characteristics (Fuller, 1985a, 1985b), they are the three years for which I have the largest samples, and the yearly samples are roughly equal in size. Numbers were high in 1974 and 1976, and low in 1978. Spring numbers, however, were much higher in 1974 than in 1976, consequently, population growth rates differed. Spring and summer were cool in 1974 and 1978, and warm in 1976.

Because age structure varies continuously during the breeding season as older animals die and new litters are born, age distribution will be sensitive to the distribution of sampling effort in time. In order to have molar class 3 represented in the annual samples, and to make meaningful interyear comparisons, I confined the analysis to individuals captured in the 7 weeks from 14 July to 31 August in each year. It is obvious (Table 1) that the distribution of catches in time was similar in 1974 and 1976, whereas trapping ended about 10 days early in 1978 , and both mean and median dates were advanced by 10 or 11 days. Because the annual peak in numbers in the study population occurs in late summer, a significant fraction of the 1974 and 1976 samples was captured in the last 10 days of August. Mean molar "age" and the distribution of body weights might well be biased in the 1978 sample (see Discussion for further consideration of this possibility.)

The spread of body weights in the samples (Figs 1 and 2) was similar in

Table 1

Temporal distribution of catches in the three years of study.

\begin{tabular}{|c|c|c|c|c|c|c|c|}
\hline \multirow[t]{2}{*}{ Year } & \multicolumn{7}{|c|}{ Date of capture } \\
\hline & First & $\begin{array}{l}25 \text { th } \\
\text { Percentile }\end{array}$ & Median & $\begin{array}{c}75 \text { th } \\
\text { Percentile }\end{array}$ & Last & Mean & S.E. \\
\hline 1974 & Jul 14 & Jul 29 & Aug 11 & Aug 27 & Aug 29 & Aug 10 & 1.40 \\
\hline 1976 & Jul 23 & Aug 4 & Aug 12 & Aug 22 & Aug 31 & Aug 12 & 0.98 \\
\hline 1978 & Jul 16 & Jul 23 & Aug 01 & Aug 07 & Aug 20 & Aug 01 & 0.85 \\
\hline
\end{tabular}




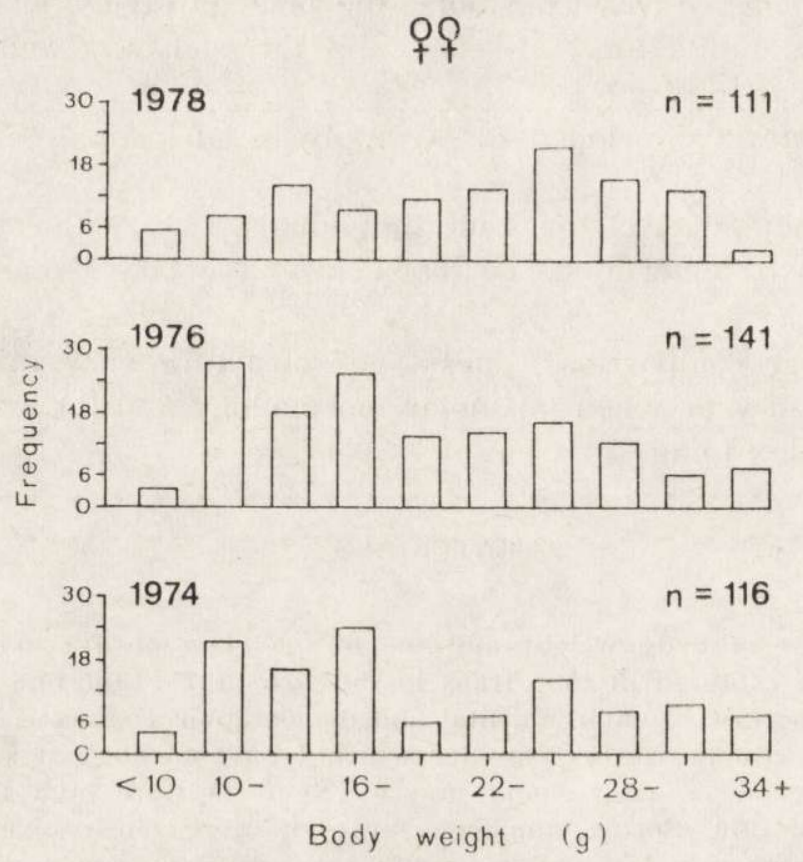

Fig. 1. Frequency distribution of body weights of females, by three-gram intervals.

ठ"ర
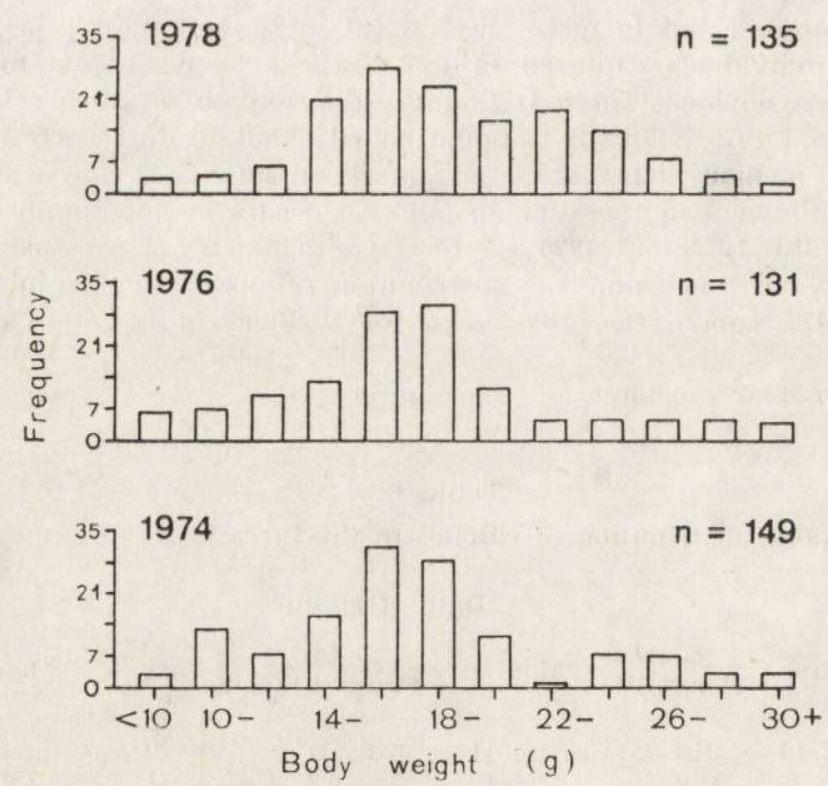

Fig. 2. Frequency distribution of body weights of males, by two-gram intervals. 
both sexes in 1974 and 1976, whereas the distributions were drawn out to the right in 1978. G-tests revealed that 1974 did not differ from 1976 for either sex $(G=5.16, d f=9, p>0.50$ for females; $G=8.08, d f=11, p>0.50$ for males), but 1978 differed strongly from the other two years combined $(G=28.06, d f=9, p<0.005$ for females; $G=5.16, d f=11, p<0.005$ for males). Mean, median, minimum and maximum weights were similar for both sexes in 1974 and 1976 (Table 2). Means and medians were larger in both sexes in 1978 than in the other years, although the differences are not statistically significant. For August only, however, both sexes were heavier in 1978 than in the other years combined in both the first half of the month $\left(F_{1,128}=6.687, p<0.025\right.$ for females; $F_{1,148}=5.156, p<0.025$ for males), and the second half $\left(F_{1,109}=8.915, p<0.005\right.$ for females; $F_{1,124}=5.011, p<0.05$ for males).

Table 2

Distribution of body weights (g) in the samples for each year.

\begin{tabular}{lllllll}
\hline Year & Sex & Min & Median & Max & Mean & S.E. \\
\hline \multirow{2}{*}{1974} & Female & 6.2 & 17.9 & 40.5 & 20.26 & 7.44 \\
& Male & 8.2 & 17.8 & 31.4 & 18.16 & 4.25 \\
1976 & Female & 7.3 & 18.5 & 36.7 & 20.09 & 6.23 \\
& Male & 7.5 & 18.0 & 32.1 & 18.39 & 4.48 \\
1978 & Female & 6.2 & 23.9 & 36.6 & 22.58 & 6.91 \\
& Male & 9.4 & 18.9 & 33.3 & 19.54 & 3.80 \\
\hline
\end{tabular}

3. METHODS

Field methods are described in Fuller (1985a). Captured individuals were weighed to the nearest $0.1 \mathrm{~g}$. In the case of pregnant females, the weight of the gravid reproductive tract was subtracted from the gross weight to give the corrected weight used in this study. No allowance was made for variation in weight of the stomach. Breeding females had either visible uterine swellings, or placental scars, or enlarged nipples. Breeding males had enlarged, scrotal testes and tubules visible to the naked eye in the enlarged cauda epididymidis. In doubtful cases their status was confirmed by presence or absence of sperm in smears of testis and epididymis. Skulls were cleaned by dermestid beetles. Each right maxilla (left if the right was damaged) was chipped away as necessary to reveal all of $\mathbf{M}^{2}$, which was then scored according to the characteristics described above.

Frequency distributions derived from molar classes were compared with distributions derived from weight classes. Differences were evaluated by means of McNemar's test for significance of changes and the G-statistic (Sokal \& Rohlf. 1969).

\section{RESULTS}

\subsection{Is there a Frequency Distribution of Body Weights} that Matches that of Molar Age Classes?

Cross tabulation was used to find weight class limits that gave the best match to the frequency distribution of molar age classes in each annual subsample and in the pooled sample. Initial guesses for upper 
and lower limits for each weight class were refined by slight adjustments and retabulation until the best fit was found. Goodness of fit was evaluated by calculating the sum of the squares $\left(D^{2}\right)$ of the differences $(\mathrm{D}(i))$ between the two distributions where $\mathrm{D}(i)=$ [number in molar class(i)] - [number in weight $\operatorname{class}(i)]$ and $i=1$ to 4 .

Weight class limits varied from year to year (Table 3), especially for molar classes 2 and 3. Class limits for 1974 and 1976 were more similar to each other than to those for 1978. Class limits also varied between the sexes.

Body weights for each annual subsample were repartitioned on the basis of class limits derived from the other two subsamples and the pooled sample. Each frequency distribution was then compared with the distribution of molar classes by means of McNemar's test for significance of changes, and by the G-test for goodness of fit between the distribution of molar classes (expected) and the distribution of weight classes (observed). The results of the NcNemar test were always the more conservative, and only they are given in Tables 4 and 5 .

The distribution of weight classes did not differ from the distribution of molar classes in the 1974 female subsample (Table 4) according to (a) weight class limits derived from the 1974 subsample, (b) weight class

Table 3

Weight class limits (g) for best fit between frequency distributions based on body weight and molar morphology.

\begin{tabular}{|c|c|c|c|c|c|c|c|}
\hline \multirow[t]{3}{*}{$\begin{array}{r}\text { Molar } \\
\text { class }\end{array}$} & \multirow[t]{3}{*}{ Year } & \multicolumn{6}{|c|}{ Class limits } \\
\hline & & \multicolumn{3}{|c|}{ Females } & \multicolumn{2}{|r|}{ Males } & \multirow{2}{*}{ Range } \\
\hline & & Min & $\operatorname{Max}$ & Range & Min & $\operatorname{Max}$ & \\
\hline 1 & $\begin{array}{l}1974 \\
1976 \\
1978 \\
74+76 \\
\text { Pooled }\end{array}$ & $\begin{array}{l}\bar{z} \\
\bar{z}\end{array}$ & $\begin{array}{l}17.1 \\
17.4 \\
18.5 \\
17.3 \\
17.4\end{array}$ & & $\begin{array}{l}\bar{z} \\
\bar{z}\end{array}$ & $\begin{array}{l}17.5 \\
17.1 \\
17.0 \\
17.3 \\
17.1\end{array}$ & \\
\hline 2 & $\begin{array}{l}1974 \\
1976 \\
1978 \\
74+76 \\
\text { Pooled }\end{array}$ & $\begin{array}{l}17.2 \\
17.5 \\
18.6 \\
17.4 \\
17.5\end{array}$ & $\begin{array}{l}24.8 \\
25.0 \\
28.0 \\
24.8 \\
25.8\end{array}$ & $\begin{array}{l}7.6 \\
7.5 \\
9.4 \\
7.4 \\
8.3\end{array}$ & $\begin{array}{l}17.6 \\
17.2 \\
17.1 \\
17.4 \\
17.2\end{array}$ & $\begin{array}{l}21.0 \\
20.4 \\
22.8 \\
20.7 \\
21.8\end{array}$ & $\begin{array}{l}3.4 \\
3.2 \\
5.7 \\
3.3 \\
4.6\end{array}$ \\
\hline 3 & $\begin{array}{l}1974 \\
1976 \\
1978 \\
74+76 \\
\text { Pooled }\end{array}$ & $\begin{array}{l}24.9 \\
25.1 \\
28.1 \\
24.9 \\
25.9\end{array}$ & $\begin{array}{l}28.0 \\
29.5 \\
28.6 \\
28.7 \\
28.8\end{array}$ & $\begin{array}{l}3.1 \\
4.4 \\
0.5 \\
3.8 \\
2.9\end{array}$ & $\begin{array}{l}21.1 \\
20.5 \\
22.9 \\
20.8 \\
21.9\end{array}$ & $\begin{array}{l}22.9 \\
22.9 \\
23.6 \\
22.9 \\
22.9\end{array}$ & $\begin{array}{l}1.8 \\
2.4 \\
0.7 \\
1.1 \\
1.0\end{array}$ \\
\hline 4 & $\begin{array}{l}1974 \\
1976 \\
1978 \\
74+76 \\
\text { Pooled }\end{array}$ & $\begin{array}{l}28.1 \\
29.6 \\
28.7 \\
28.8 \\
28.9\end{array}$ & $\begin{array}{l}\overline{-} \\
\overline{-}\end{array}$ & & $\begin{array}{l}23.0 \\
23.0 \\
23.7 \\
23.0 \\
23.0\end{array}$ & $\begin{array}{l}\bar{z} \\
\overline{-}\end{array}$ & \\
\hline
\end{tabular}


limits derived from the 1976 subsample, (c) weight class limits derived from the 1974 and 1976 subsamples combined, and (d) weight class limits derived from the pooled sample. However, the two distributions differed strongly when weights were partitioned by means of the weight class limits derived from the 1978 subsample. Essentially the same picture is presented by the 1976 female subsample and by the combined 1974 and 1976 subsample. However, the distribution of body weights differed strongly from the distribution of molar classes in the 1978 female subsample except when weight class limits derived from the 1978 subsample were applied. Weight class limits for each annual subsample gave distributions of body weights that difered from the distribution of molar classes in the pooled sample.

l'able 4

Percentage of females in each "age" class in subsamples taken in three separate years, and in pooled samples, classified according to molar morphology and body weight. Body weights for each annual subsample were tabulated according to class limits dorived from the subsample for that year, for each other year, and for pooled samples. Chi-squared values are from McNemar's test for significance of changes.

\begin{tabular}{|c|c|c|c|c|c|c|c|c|c|}
\hline \multirow[t]{2}{*}{$\begin{array}{r}\text { Sample } \\
\text { year }\end{array}$} & \multirow[t]{2}{*}{ Method } & \multirow[t]{2}{*}{$\begin{array}{c}\text { Class limits } \\
\text { year }\end{array}$} & \multicolumn{5}{|c|}{ "Age" classes } & \multirow[t]{2}{*}{$\chi^{2}$} & \multirow[t]{2}{*}{$p$} \\
\hline & & & $n$ & 1 & 2 & 3 & 4 & & \\
\hline \multirow[t]{6}{*}{1974} & Molar & & \multirow[t]{6}{*}{116} & 45.7 & 20.7 & 13.8 & 19.8 & & \\
\hline & Weight & 1974 & & 44.8 & 21.5 & 13.8 & 19.8 & & \\
\hline & Weight & 1976 & & 48.3 & 19.0 & 17.2 & 15.5 & 1.39 & NS \\
\hline & Weight & 1578 & & 54.3 & 25.9 & 1.7 & 18.1 & 16.62 & $<0.005$ \\
\hline & Weight & $74+76$ & & 45.7 & 20.7 & 13.8 & 19.8 & 0.51 & NS \\
\hline & Weight & Pooled & & 48.3 & 23.3 & 11.2 & 17.2 & 1.46 & NS \\
\hline \multirow[t]{6}{*}{1976} & Molar & & \multirow[t]{6}{*}{141} & 46.1 & 24.1 & 15.6 & 14.2 & & \\
\hline & Weight & 1973 & & 46.1 & 24.8 & 14.9 & 14.2 & & \\
\hline & Weight & 1974 & & 44.0 & 26.9 & 11.3 & 17.7 & 1.45 & NS \\
\hline & Weikht & 1978 & & 50.3 & 31.9 & 0.7 & 17.0 & 18.85 & $\ll 0.005$ \\
\hline & Weight & $74+76$ & & 46.1 & 24.1 & 15.6 & 14.2 & 0.16 & NS \\
\hline & Weight & Pooled & & 46.1 & 29.8 & 7.8 & 16.3 & 3.51 & NS \\
\hline \multirow[t]{6}{*}{1978} & Nolar & & \multirow[t]{6}{*}{111} & 32.4 & 42.3 & 2.7 & 22.5 & & \\
\hline & Weight & 1978 & & 32.4 & 41.4 & 3.6 & 22.5 & & \\
\hline & Weig'it & 1976 & & 29.7 & 27.9 & 23.4 & 18.9 & 20.04 & $\ll 0.005$ \\
\hline & Weight & 1974 & & 28.8 & 25.2 & 19.8 & 26.1 & 20.23 & $\ll 0.005$ \\
\hline & Weight & $74+76$ & & 32.4 & 42.3 & 2.7 & 22.5 & 22.48 & $\ll 0.005$ \\
\hline & Weight & Pooled & & 29.7 & 32.4 & 16.2 & 21.6 & 12.28 & $<0.01$ \\
\hline \multirow[t]{6}{*}{$74+76$} & Molar & & \multirow[t]{6}{*}{257} & 45.9 & 22.6 & 14.8 & 16.7 & & \\
\hline & Weight & $74+76$ & & 46.3 & 22.6 & 14.4 & 16.7 & & \\
\hline & Weight & Pooled & & 47.1 & 26.9 & 9.3 & 16.7 & 4.78 & NS \\
\hline & Weight & 1974 & & 44.4 & 24.5 & 12.5 & 18.7 & 0.85 & NS \\
\hline & Weight & 1976 & & 47.1 & 22.2 & 15.9 & 14.8 & 0.93 & NS \\
\hline & Weight & 1978 & & 52.1 & 29.2 & 1.2 & 17.5 & 36.53 & $\ll 0.005$ \\
\hline \multirow[t]{6}{*}{ Pooled } & Molar & & \multirow[t]{6}{*}{368} & 41.9 & 28.5 & 11.1 & 18.5 & & \\
\hline & Weight & Pooled & & 41.9 & 28.5 & 11.4 & 18.2 & & \\
\hline & Weight & 1974 & & 39.7 & 24.7 & 14.7 & 20.9 & 9.88 & $<0.025$ \\
\hline & Weight & 1976 & & 41.9 & 23.9 & 18.2 & 16.0 & 8.21 & $<0.05$ \\
\hline & Weight & $74+76$ & & 41.0 & 23.4 & 17.1 & 18.5 & 9.05 & $<0.05$ \\
\hline & Weight & 1978 & & 46.2 & 32.9 & 1.9 & 19.0 & 28.79 & $\ll 0.005$ \\
\hline
\end{tabular}


A rather similar picture is presented by the males (Table 5), except that differences are less extreme than in females. In fact, no significant difference appeared in the 1974 subsample, and only one marginally significant difference in the 1976 subsample. However, the distribution of body weight classes was clearly different in 1978 from the distribution in the other two years.

Thus, there is no single set of weight class limits, even that derived from the pooled sample, that applies to all subsamples, although there is considerable similarity between the two years of high numbers, 1974 and 1976.

Table 5

\begin{tabular}{|c|c|c|c|c|c|c|c|c|c|}
\hline \multirow[t]{2}{*}{$\begin{array}{c}\text { Sample } \\
\text { year }\end{array}$} & \multirow[t]{2}{*}{ Method } & \multirow[t]{2}{*}{$\begin{array}{l}\text { Class limits } \\
\text { year }\end{array}$} & \multirow[b]{2}{*}{$n$} & \multicolumn{4}{|c|}{ "Age" classes } & \multirow[t]{2}{*}{$\chi^{2}$} & \multirow[t]{2}{*}{$p$} \\
\hline & & & & 1 & 2 & 3 & 4 & & \\
\hline 1974 & $\begin{array}{l}\text { Molar } \\
\text { Weight } \\
\text { Weight } \\
\text { Weight } \\
\text { Weight } \\
\text { Weight }\end{array}$ & $\begin{array}{l}1974 \\
1976 \\
1978 \\
74+76 \\
\text { Pooled }\end{array}$ & 135 & $\begin{array}{l}43.7 \\
43.7 \\
39.3 \\
37.8 \\
41.5 \\
39.3 \\
\end{array}$ & $\begin{array}{l}37.0 \\
36.3 \\
38.5 \\
45.9 \\
36.3 \\
44.4\end{array}$ & $\begin{array}{l}3.7 \\
3.7 \\
5.9 \\
0.7 \\
5.9 \\
0.0\end{array}$ & $\begin{array}{l}15.6 \\
16.3 \\
16.3 \\
15.6 \\
16.3 \\
16.3\end{array}$ & $\begin{array}{l}0.72 \\
3.13 \\
0.20 \\
4.03\end{array}$ & $\begin{array}{l}\text { NS } \\
\text { NS } \\
\text { NS } \\
\text { NS }\end{array}$ \\
\hline 1976 & $\begin{array}{l}\text { Molar } \\
\text { Weight } \\
\text { Weight } \\
\text { Weight } \\
\text { Weight } \\
\text { Weight }\end{array}$ & $\begin{array}{l}1976 \\
1974 \\
1978 \\
74+76 \\
\text { Pooled }\end{array}$ & 131 & $\begin{array}{l}39.7 \\
38.9 \\
45.0 \\
38.9 \\
42.8 \\
38.9\end{array}$ & $\begin{array}{l}36.6 \\
36.6 \\
34.3 \\
45.0 \\
35.9 \\
42.7\end{array}$ & $\begin{array}{l}7.6 \\
9.2 \\
5.3 \\
1.5 \\
6.1 \\
3.1 \\
\end{array}$ & $\begin{array}{l}16.0 \\
15.3 \\
15.3 \\
14.5 \\
15.3 \\
15.3\end{array}$ & $\begin{array}{l}1.99 \\
8.60 \\
0.65 \\
3.27\end{array}$ & $\begin{array}{c}\text { NS } \\
<0.05 \\
\text { NS } \\
\text { NS }\end{array}$ \\
\hline 1978 & $\begin{array}{l}\text { Molar } \\
\text { Weight } \\
\text { Weight } \\
\text { Weight } \\
\text { Weight } \\
\text { Weight }\end{array}$ & $\begin{array}{l}1978 \\
1976 \\
1974 \\
74+76 \\
\text { Pooled }\end{array}$ & 149 & $\begin{array}{l}30.2 \\
30.9 \\
32.2 \\
38.9 \\
35.6 \\
32.2\end{array}$ & $\begin{array}{l}45.6 \\
46.3 \\
28.9 \\
25.5 \\
27.5 \\
35.6\end{array}$ & $\begin{array}{r}2.7 \\
2.7 \\
16.1 \\
12.7 \\
14.1 \\
9.4\end{array}$ & $\begin{array}{l}21.5 \\
20.1 \\
22.8 \\
22.8 \\
22.8 \\
22.8\end{array}$ & $\begin{array}{r}15.59 \\
16.70 \\
15.37 \\
7.40\end{array}$ & $\begin{array}{l}<0.005 \\
<0.005 \\
<0.005 \\
<0.01\end{array}$ \\
\hline $74+76$ & $\begin{array}{l}\text { Molar } \\
\text { Weight } \\
\text { Weight } \\
\text { Weight } \\
\text { Weight } \\
\text { Weight }\end{array}$ & $\begin{array}{l}74+76 \\
\text { Pooled } \\
1974 \\
1976 \\
1978\end{array}$ & 266 & $\begin{array}{l}41.7 \\
42.1 \\
39.1 \\
44.4 \\
39.1 \\
38.3\end{array}$ & $\begin{array}{l}36.8 \\
36.1 \\
43.6 \\
35.3 \\
37.6 \\
45.5\end{array}$ & $\begin{array}{l}5.6 \\
6.0 \\
1.5 \\
4.5 \\
7.5 \\
1.1\end{array}$ & $\begin{array}{l}15.8 \\
15.8 \\
15.8 \\
15.8 \\
15.8 \\
15.0\end{array}$ & $\begin{array}{r}8.17 \\
1.76 \\
1.34 \\
12.15\end{array}$ & $\begin{array}{r}<0.05 \\
\text { NS } \\
\text { NS } \\
<0.01\end{array}$ \\
\hline Pooled & $\begin{array}{l}\text { Molar } \\
\text { Weight } \\
\text { Weight } \\
\text { Weight } \\
\text { Weight } \\
\text { Weight }\end{array}$ & $\begin{array}{l}\text { Pooled } \\
1974 \\
1976 \\
74+76 \\
1978\end{array}$ & 415 & $\begin{array}{l}37.6 \\
36.6 \\
42.4 \\
36.6 \\
39.8 \\
35.7\end{array}$ & $\begin{array}{l}40.0 \\
40.7 \\
31.8 \\
34.5 \\
33.0 \\
45.8\end{array}$ & $\begin{array}{r}4.6 \\
4.3 \\
7.5 \\
10.6 \\
8.9 \\
1.7 \\
1.7\end{array}$ & $\begin{array}{l}17.8 \\
18.3 \\
18.3 \\
18.3 \\
18.3 \\
16.9\end{array}$ & $\begin{array}{r}7.81 \\
11.27 \\
7.50 \\
10.31\end{array}$ & $\begin{aligned} & 0.05 \\
< & 0.025 \\
< & 0.10 \\
< & 0.025\end{aligned}$ \\
\hline
\end{tabular}




\subsection{Does Sexual Maturation Play a Role?}

For this analysis weight class limits for the pooled sample were applied to the sexually mature component of each annual subsample, as well as the pooled sample, and the distributions of weight classes and molar classes were compared. Although the overall difference in the two distributions for the pooled sample of all females (Table 6) is not statistically significant, the two methods of classification differ considerably in the assignment of individuals to classes 1 and 2. A separate analysis of classes 1 and 2 revealed a marginally significant difference (McNemar's test, $\chi^{2}=4.08, p<0.05$ ). No significant difference appeared in 1974 or 1976 , but in the 1978 subsample there was a very significant difference between the two frequency distributions. Classification by

\section{Table 6}

Percentage of breeding females in each "age" category, classified according to molar tooth morphology and body weight. Weight criteria determined from the pooled sample of all females were applied to the subsample of breeding females.

\begin{tabular}{|c|c|c|c|c|c|c|c|c|}
\hline \multirow[t]{2}{*}{ Year } & \multirow[t]{2}{*}{$n$} & \multirow[t]{2}{*}{ Method } & \multicolumn{4}{|c|}{ "Age" class } & \multirow[t]{2}{*}{$\chi^{2}$} & \multirow[t]{2}{*}{$p$} \\
\hline & & & 1 & 2 & 3 & 4 & & \\
\hline \multirow[t]{2}{*}{ Pooled } & 184 & Molar & 5.4 & 35.3 & 22.3 & 37.0 & & \\
\hline & & Weight & 1.1 & 39.7 & 22.8 & 36.4 & 5.551 & NS \\
\hline \multirow[t]{2}{*}{1974} & 52 & Molar & 3.9 & 21.1 & 30.8 & 44.2 & & \\
\hline & & Weight & 0.0 & 36.5 & 25.0 & 38.5 & 1.692 & NS \\
\hline \multirow[t]{2}{*}{1976} & 60 & Molar & 3.3 & 26.7 & 36.7 & 33.3 & & \\
\hline & & Weight & 0.0 & 43.3 & 18.3 & 38.3 & 5.028 & NS \\
\hline \multirow[t]{2}{*}{1978} & 72 & Molar & 8.3 & 52.8 & 4.2 & 34.7 & & \\
\hline & & Weight & 2.8 & 38.9 & 25.0 & 33.3 & 13.139 & $<0.005$ \\
\hline
\end{tabular}

weight greatly underestimated the contribution to breeding of the two youngest molar classes and overestimated the contribution of molar class 3 . Thus, the general picture for breeding females (Table 6) is much the same as that for all females (Table 4), but differences in classification, where they exist, are more pronounced in the subsample of mature animals.

There was a significant difference between frequency distributions in the 1978 subsample of mature males also (Table 7), which resulted from underestimation of the contribution of the youngest age classes, and overestimation of the importance of class 3 , by the weight method. No such difference appeared in the 1978 subsample of all males (Table 5), which suggests that weight criteria developed for the whole sample may not apply to the sexually mature component. 
Table 7

Percentage of breeding males in each "age" category, classified according to molar tooth morphology and body weight. Weight criteria determined from the pooled sample of all males were applied to the subsamples of breeding males.

\begin{tabular}{|c|c|c|c|c|c|c|c|c|}
\hline \multirow[t]{2}{*}{ Year } & \multirow[t]{2}{*}{$n$} & \multirow[t]{2}{*}{ Method } & \multicolumn{4}{|c|}{ "Age" class } & \multirow[t]{2}{*}{$\chi_{2}$} & \multirow[t]{2}{*}{$p$} \\
\hline & & & 1 & 2 & 3 & 4 & & \\
\hline \multirow[t]{2}{*}{ Pooled } & \multirow[t]{2}{*}{183} & Molar & 10.9 & 39.9 & 8.7 & 40.4 & \multirow[b]{2}{*}{4.014} & \multirow[b]{2}{*}{ NS } \\
\hline & & $\begin{array}{l}\text { Weight } \\
\text { Molar }\end{array}$ & $\begin{array}{r}6.0 \\
10.9\end{array}$ & $\begin{array}{l}42.6 \\
32.6\end{array}$ & $\begin{array}{r}9.8 \\
10.9\end{array}$ & $\begin{array}{l}41.5 \\
45.6\end{array}$ & & \\
\hline 1974 & 46 & Weight & 4.4. & 47.8 & 0.0 & 47.8 & 4.000 & NS \\
\hline \multirow[t]{2}{*}{1976} & \multirow[t]{2}{*}{43} & Molar & 7.0 & 27.9 & 16.3 & 48.8 & \multirow[b]{2}{*}{1.125} & \multirow[b]{2}{*}{ NS } \\
\hline & & $\begin{array}{l}\text { Weight } \\
\text { Molar }\end{array}$ & $\begin{array}{r}9.3 \\
12.8\end{array}$ & $\begin{array}{l}34.9 \\
48.9\end{array}$ & $\begin{array}{l}9.3 \\
4.3\end{array}$ & $\begin{array}{l}46.5 \\
34.0\end{array}$ & & \\
\hline 1978 & 94 & Weight & 5.3 & 43.6 & 14.9 & 36.2 & 11.369 & $<0.025$ \\
\hline
\end{tabular}

Comparisons of mean weights of mature and immature individuals in molar classes 1 and 2 yielded additional information on this point. In both age groups and both sexes the mean weight of mature individuals was greater than the mean weight of immatures $(p<0.001$ for all comparisons in the pooled samples). Covariance between weight and maturity is high (32.77 in females; 16.94 in males), which means that individuals that grow fast mature early. Covariance is low between molar class and maturity , 0.422 for females; 0.338 for males).

\subsection{Do Both Indices Select for the Same Individuals?}

If the answer to this question were "yes", there should be one bar and three empty classes in each of the distributions shown in Figs. 3 and 4. Molar class and modal weight coincide for weight classes 1, 2, and 4 , but weight class 3 contains more individual in molar classes 2 and 4 than in class 3 . Concordance between the two indices ran from $21 \%$ in class 3 to $86 \%$ in class 1 for females, and from $6 \%$ (class 3 ) to 91\% (class 4) in males. Among females (Fig. 3), weight class 2 contained individuals of all four molar classes, weight classes 3 and 4 contained individuals of three molar classes. Among males (Fig. 4), both weight classes 2 and 4 contained representatives of all four molar classes.

Clearly, body weight is a poor predictor of the molar class to which a given individual belongs. It is essentially useless for recognizing members of the various cohorts born during the summer breeding season, and cannot even separate all overwintered individuals from young of the year. 
†

We ght $<17.5$

$17.5-25.89$
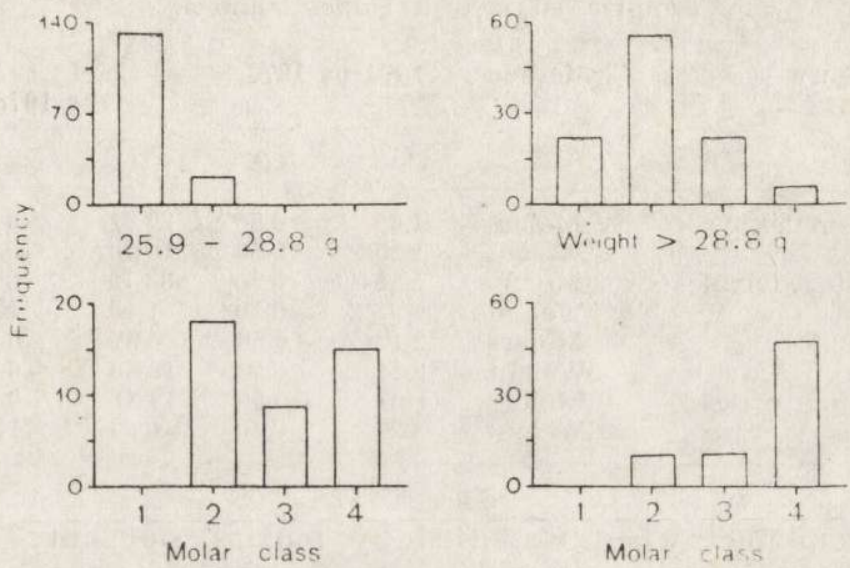

Wiight $>28.8$

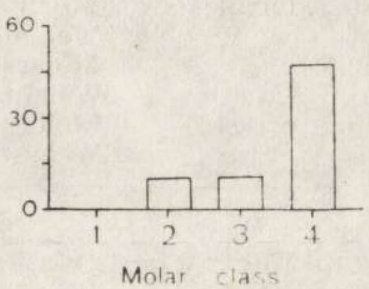

Fig. 3. Frequency distribution of females by molar slass in each weight class. Weight class limits are those derived from the pooled sample.

80

Weight $<17.2 \mathrm{~g}$

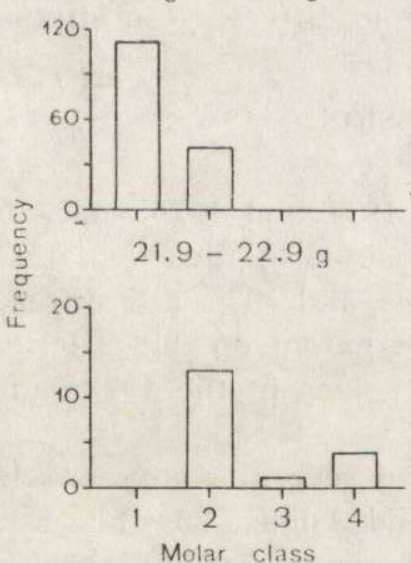

$17.2-21.8 \mathrm{~g}$

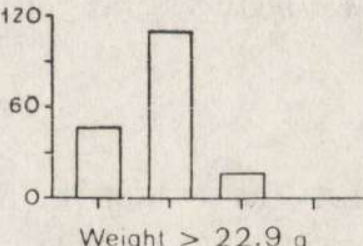

Weight $>22.9 \mathrm{~g}$

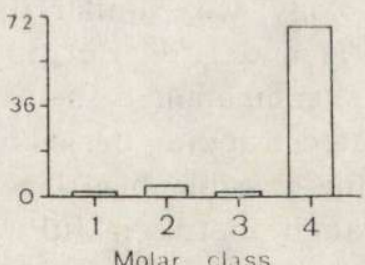

Fig. 4. Frequency distribution of males by molar class in each weight class. Weight class limits are those derived from the pooled sample.

\subsection{Interyear Comparisons}

$G$-test revealed that the distribution of age classes, whether based on molar morphology or weight classes, was similar in 1974 and 1976 (Table 8), so I combined them for comparisons with 1978. Age structure in the sample of all females differed strongly between 1978 and the other 
Table 8

Results of interyear comparisons of "age" -class distributions based on molar morphology and weight classes derived from the pooled sample. Data are in Tables 4 and 5.

\begin{tabular}{|c|c|c|c|c|c|}
\hline \multirow[t]{2}{*}{ Category } & \multirow[t]{2}{*}{ Method } & \multicolumn{2}{|c|}{1974 vs 1976} & \multicolumn{2}{|c|}{$\begin{array}{c}1974+1976 \\
\text { vs } 1978\end{array}$} \\
\hline & & G & $p$ & G & $p$ \\
\hline All females & Molars & 1.68 & $>0.50$ & 27.81 & $\ll 0.005$ \\
\hline Breeding females & Molars & $\begin{array}{l}1.90 \\
1.52\end{array}$ & $>0.50$ & $\begin{array}{l}10.78 \\
33.70\end{array}$ & $\ll 0.005$ \\
\hline All males & $\begin{array}{l}\text { Weight } \\
\text { Molars }\end{array}$ & $\begin{array}{l}0.91 \\
2.12\end{array}$ & $\begin{array}{l}>0.50 \\
>0.50\end{array}$ & $\begin{array}{r}1.48 \\
8.97\end{array}$ & $\therefore \quad \begin{array}{l}\text { NS } \\
\leq 0.05\end{array}$ \\
\hline & Weight & 2.11 & $>0.50$ & 18.48 & $<0.005$ \\
\hline Breeding males & $\begin{array}{l}\text { Molars } \\
\text { Weight }\end{array}$ & $\begin{array}{l}1.07 \\
3.86\end{array}$ & $>0.50$ & $\begin{array}{r}11.21 \\
6.89\end{array}$ & $\begin{array}{c}<0.01 \\
\text { NS }\end{array}$ \\
\hline
\end{tabular}

two years combined when classified by molars, but only marginally when classified by body weight. In the sample of all males, on the other hand, a highly significant difference appeared in the distribution of body weight classes, but only a marginal difference in the distribution of molar classes. In the subsamples of breeding individuals, classification by molars revealed a significant difference in both sexes, whereas classification by body weight revealed no difference in either sex.

\section{DISCUSSION}

Since numbers were high in both 1974 and 1976, and low in 1978, it is not surprising that the age composition of the population, based on molar morphology, was similar in 1974 and 1976, and different in 1978 from both 1974 and 1976. But, to what extent do the differences reflect a biological phenomenon rather than a bias in the 1978 sample caused by the truncated trapping period?

To check for possible bias I repeated several analyses, selecting only individuals caught between July 23 and August 20 when sampling was in progress in all three years. The frequency distribution of male molar classes still varied significantly among years $(G=14.036, d f=6, p \cong 0.025)$, 1974 did not differ from $1976(G=0.297)$, and 1978 differed strongly from the other two years combined $(G=13.739, d f=3, p<0.005)$. For females, the results were similar. Among all three years, $G=29.020$, $d f=6, p \ll 0.005$, and for 1978 versus the other two years combined, $G=27.840, d f=3, p \ll 0.005$.

I also compared mean molar ages and mean weights by Mann-Whitney $U$-test for both the whole period and the restricted period. The values changed only marginally. 
Finally, I compared August values (Table 9). If mean body weight was higher in late August than in early August, any bias in mean weight in 1978 should be in the direction of a lower mean weight in 1978 than in the other years because of the limited sampling in late August. In each year, and both sexes, mean weights were higher in late August than in early August although the differences are not statistically significant except for males in 1978 .

I conclude from these analyses that the differences between the 1978 sample and samples for the other two years were real rather than a function of the truncated sampling season in 1978.

It is clear that the frequency distribution of molar classes can be closely approximated by choosing an appropriate set of weight class limits, but it is equally clear that weight class limits derived from a sample taken in a given year may not apply to samples taken in any other year (Tables 4 and 5). Classification by molar morphology, but not

Table 9

Mean body weights (g) of samples taken in early (1-15) and late (16-31) Aligust.

\begin{tabular}{lllllcr}
\hline Sex & Year & Early & Late & \multicolumn{1}{c}{$d f$} & F & $p$ \\
\hline Female & 1974 & 19.46 & 20.27 & 1,78 & 0.2270 & NS \\
& 1976 & 17.81 & 19.28 & 1,107 & 1.0683 & NS \\
& 1978 & 22.58 & 25.36 & 1,50 & 1.4601 & NS \\
Male & 1974 & 17.18 & 17.90 & 1,93 & 0.6354 & NS \\
& 1976 & 16.98 & 18.50 & 1,104 & 2.9804 & NS \\
& 1978 & 18.85 & 20.35 & 1,73 & 2.2541 & NS \\
\hline
\end{tabular}

by body weight showed a difference in age structure for the sexually mature segment of the samples (Table 8). Obviously, different demographic conclusions would be drawn from these results depending on whether molars or body weight were used as an index to age. Even when the match in frequency distributions is nearly perfect, body weight is a poor index to the molar class to which an individual belongs (Figs 3 and 4). This finding has particular significance for live-trapping studies, where weight may be the only available index.

Although Mihok (1980) followed the development of $\mathrm{M}^{2}$ in knownaged $C$. gapperi raised in captivity, and although the timing of those events was quite precise in his sample, questions remain. Is the rate of development the same in wild as in captive animals? Does the rate vary from year to year, perhaps in response to differences in environmental, social, or nutritional conditions? Does it vary from place to place, 
perhaps in response to different foods that cause different rates of attrition? In short, is molar development any more constant from year to year and season to season than body weight? There is no definitive answer to that question at the present time, but there are reasons to think that it may be so.

First, molar development is unidirectional, i.e. a tooth that has formed a neck or a root never reverts to an earlier stage, whereas body weight, as is well known, can decrease as well as increase (Koshkina, 1955; Zejda, 1965; Sealander, 1966; Fuller, 1977 and unpublished). Second, body weight is apparently sensitive to temperature (Fuller, 1985b), density (Chitty, 1955), and presumably nutrition, whereas molar growth has not been shown to be sensitive to any of those factors. Finally, no conceivable amount of variability in molar development could result in failure to differentiate overwintered individuals from young of the year, without error, and at any season.

While this paper deals only with Clethrionomys spp., I suggest that weight is no more reliable as an index to age in other microtine genera. When conclusions about population dynamics depend on differences in "age" structure, they should be accepted with caution if body weight is used as the sole index to age.

\section{REFERENCES}

1. Chitty D., 1955: Adverse effects of population density upon the viability of later generations. [In "The Numbers of Man and Animals" J. B. Cragg and N. W. Pirie, Eds J. Oliver and Boyd: $57-67$. Edinburgh.

2. Fuller W. A,, 1977: Demography of a subarctic population of Clethrionomys gapperi: size and growth. Can. J. Zool., 55: 415-425.

3. Fuller W. A., 1985a: Clethrionomys gapperi: is there a peak syndrome? Ann. Zool. Fennici, 22: 243-255.

4. Fuller W. A., 1985b: Demography of parapatric Clethrionomys gapperi and C. rutilus, and sympatric Peromyscus maniculatus in northern Canada. Ann. Zool. Fennici, 22: 229-241.

5. Koshkina T. V., 1955: Method opredelenija vozrasta ryžih polevok i opyt ego primenenija. Zool. Ž., 34: 631-639.

6. Martell A. M. \& Fuller W. A., 1979: Comparative demography of Clethrionomys rutilus in taiga and tundra in the low Arctic. Can. J. Zool., 57: $2106-2120$.

7. Mihok S. 1980: Ageing young Clethrionomys gapperi with $\mathrm{M}^{2}$ tooth characteristics. Can. J. Zool., 58: 2280-2281.

8. Schwarz S. S., Pokrovski V. A., Istchenko V. G., Istchenko V. G., Olenjev V. G., Ovtschinnikova N. A. \& Pjastolova O. A., 1964: Biological peculiarities of seasonal generations of rodents, with special reference to the problem of senescence in mammals. Acta theriol., $8: 11-41$. 
9. Sealander J. H., 1966: Seasonal variations in hemoglobin and hematocrit values in the red-backed mouse, Clethrionomys rutilus dawsoni (Merriam) in interior Alaska. Can. J. Zool., 44, 213-224.

10. Sokal R. R. \& Rohlf F. J., 1969: Biometry: The principles and practice of statistics in biological research. 1-776.

11. Tupikova N. V., Sidorova G. A. \& Konovalova E. A., 1968: A method of age determination in Clethrionomys. Acta theriol., 13: 99-113.

12. Zejda J., 1965: Das Gewicht, das Alter und die Geslechtsaktivität bei der Rötelmaus (Clethrionomys glareolus Schreb.). Z. Säugetierk., 30: 1-9.

13. Zejda J., 1971: Differential growth of three cohorts of the bank vole, Clethrionomys glareolus Schreb. 1780. Zool. Listy, 20: 229-245.

Received 25 September 1987, Accepted 30 March 1988.

William A. FULLER

CZY MASA JEST WIARYGODNYM WSKAŻNIKIEM WIEKU U NORNIKOWATYCH?

\section{Streszczenie}

Sporządzono rozkłady frekwencji nornic Clethrionomys gapperi (Vigors, 1830) w klasach wieku oznaczonego na podstawie masy ciała, stopnia wykształcenia korzeni drugiego dolnego trzonowca $\left(\mathrm{M}_{2}\right)$ i jego morfologii. Porównano próby $\mathrm{z}$ tych samych lat i między latami. Przedziały masy, które były najlepiej dopasowane do przedziałów wieku określonego wg zębów zmieniały się z roku na rok. Masa ciała okazała się więc słabym wskaźnikiem wieku osobnika. W porównaniach między latami (Tabela 8) rozklady wiekowe oparte na masie ciała były istotnie różne od rozkładów opartych na morfologii $\mathrm{M}_{2}$. Wobec tego wnioskowanie o strukturze wieku i dynamice populacji Clethrionomys i innych nornikowatych na na podstawie masy ciała osobników powinno być bardzo ostrożne. 